\title{
The efficiency of lactic acid bacteria against pathogenic fungi and mycotoxins
}

\author{
Adam Perczak ${ }^{1}$, Piotr Goliński ${ }^{1}$, Marcin Bryła르, and Agnieszka Waśkiewicz ${ }^{1}$ \\ Department of Chemistry, Poznan University of Life Sciences, Poznañ ${ }^{1}$, Department of Food Analysis, Prof. Waclaw \\ Dabrowski Institute of Agricultural and Food Biotechnology, Warsaw², Poland
}

[Received in October 2017; Similarity Check in October 2017; Accepted in March 2018]

\begin{abstract}
Mycotoxins are produced by some fungal species of the genera Aspergillus, Penicillium, and Fusarium and are common contaminants of a wide range of food commodities. Numerous strategies are used to minimise fungal growth and mycotoxin contamination throughout the food chain. This review addresses the use of lactic acid bacteria, which can inhibit fungal growth and participate in mycotoxin degradation and/or removal from contaminated food. Being beneficial for human and animal health, lactic acid bacteria have established themselves as an excellent solution to the problem of mycotoxin contamination, yet in practice their application in removing mycotoxins remains a challenge to be addressed by future research.
\end{abstract}

KEY WORDS: Aspergillus; biological methods; Fusarium; inhibition; LAB; Penicillium

Mycotoxin contamination of feed and food is a significant issue worldwide. Mycotoxins are a large group of secondary metabolites produced by the Aspergillus, Penicillium, and Fusarium genera, and pose serious risks for human and animal health (1-4). Fungal growth and mycotoxin production may occur in the field and/or during storage, if the temperature and humidity are favourable (4-8).

The main sources of mycotoxins are cereal grains (including wheat, barley, oats, corn, and rice) and their products, nuts, almonds, fruits, coffee, spices, and legumes $(5,6,9-11)$ (Table 1).

Table 1 The main sources of mycotoxins

\begin{tabular}{|c|c|c|c|}
\hline Mycotoxin & Species of fungi & Main source & References \\
\hline Aflatoxins & $\begin{array}{l}\text { Aspergillus flavus, } \\
\text { Aspergillus parasiticus }\end{array}$ & $\begin{array}{l}\text { peanuts, oilseed cereals, } \\
\text { cow's milk, sorghum, spices }\end{array}$ & $(12-18)$ \\
\hline Ochratoxins & $\begin{array}{l}\text { Aspergillus ochraceus, } \\
\text { A. sulphureus, } \\
\text { Penicillum verucosum }\end{array}$ & $\begin{array}{l}\text { cereal grain storage, feed, } \\
\text { grapes, wine, coffee }\end{array}$ & $(19-23)$ \\
\hline Trichothecenes & $\begin{array}{l}\text { Fusarium poae, } \\
\text { F. sporotrichioides, } \\
\text { F. acuminatum, } \\
\text { F. equiseti }\end{array}$ & $\begin{array}{l}\text { wheat, barley, maize, oat, buckwheat, } \\
\text { sorghum, feed }\end{array}$ & $(1,24-34)$ \\
\hline Zearalenone & $\begin{array}{c}\text { Fusarium graminearum, } \\
\text { F. culmorum, } \\
\text { F. cerealis }\end{array}$ & $\begin{array}{l}\text { maize, wheat, barley, oat, sorghum, rice, } \\
\text { pea, feed }\end{array}$ & $(1,26,35-40)$ \\
\hline Fumonisins & $\begin{array}{l}\text { Fusarium verticillioides, } \\
\text { F. proliferatum }\end{array}$ & $\begin{array}{l}\text { maize and other cereals and their } \\
\text { products, asparagus }\end{array}$ & $(41-44)$ \\
\hline Patulin & $\begin{array}{l}\text { Penicillum expansum, } \\
\text { P. cyclopium }\end{array}$ & apples, pears, apple juice & $(45-47)$ \\
\hline
\end{tabular}

Correspondence to: Agnieszka Waśkiewicz, Department of Chemistry, Poznan University of Life Sciences, Wojska Polskiego 75, Poznań, Poland, E-mail:agat@up.poznan.pl 
As they enter the food chain, mycotoxins can also contaminate eggs, milk, and meat and accumulate in different organs or tissues $(9,11,48)$.

Long-term exposure to mycotoxins has also been associated with carcinogenic, mutagenic, teratogenic, oestrogenic, haemorrhagic, immunotoxic, nephrotoxic, hepatotoxic, neurotoxic, and immunosuppressive adverse health effects (48-51).

Because of these risks, the EU has set down limits for several important mycotoxins in food and feed: aflatoxins (AFs), ochratoxin A (OTA), fumonisins (FBs), zearalenone (ZEA), trichothecenes [principally deoxynivalenol (DON), T-2, and HT-2 toxins], and patulin (PAT) (9).

A number of studies have investigated the options of eliminating these compounds (52-54), and arrived at the conclusion that the best way to solve the problem is to prevent mycotoxin formation. To do that, the following rules need to be observed: (i) plant materials should be stored in a cold and dry environment, (ii) plants should be harvested without delay, (iii) crops should be rotated in the field to prevent adaptation of pathogenic microorganisms to a specific monoculture, and (iv) agricultural crops should be handled carefully to prevent mechanical damage, which renders them vulnerable to contamination $(52,53,55)$.

There where prevention fails, chemical, physical, or biological methods of detoxification step in (56-58). Some of these methods, such as the use of ozone (59-62), alkaline hydrogen peroxide $(63)$, or gamma irradiation $(64,65)$ have more promising results than ammoniation (66) or heat treatment (67-69).

However, contamination with several mycotoxins at the same time lessens the efficiency of detoxification, as some mycotoxins are less sensitive to the method than others.

Recently, a new approach to the removal of mycotoxins emerged, and microorganisms such as propionic fermentation bacterium Saccharomyces cerevisiae, and lactic acid bacteria (LAB) have come into focus. This article reviews the current uses of the latter as promising probiotics in mycotoxin removal.

\section{Lactic acid bacteria}

Lactic acid bacteria (LAB) are Gram-positive, nonsporulating, air and acid tolerant, organotrophic, fermentative rods or cocci producing lactic acid. They do not use oxygen as an electron acceptor. Not possessing catalase, they synthesise superoxide dismutase, removing reactive oxygen species. All the lactic acid bacteria are anaerobic, while some of them tolerate low levels of oxygen in the environment. Currently, only a few are considered to be probiotic, and, together with prebiotics, these have been used in nutrition and treatment of people and farm animals, such as pigs. When homofermentative, LAB ferment $85 \%$ of glucose into lactic acid. In heterofermentation (70) the yield is $50 \%$ plus ethanol and $\mathrm{CO}_{2}$.
There are a variety of industrially important genera, including Lactococcus, Enterococcus, Oenococcus, Pediococcus, Streptococcus, Leuconostoc, and Lactobacillus species (71). Yet, LAB have been used to preserve food and beverages since the beginnings of agriculture (72). Different strains of LAB have been passed down from generation to generation through culinary traditions and fermented food. Currently, LAB play a significant role in the world food production, performing major bioconversions in fermented dairy products, vegetables, and meat. They are also essential for the production of silage, coffee, wine, cocoa, sourdough, and many indigenous fermented foods (73-75). LAB improve flavour, texture, and shelf-life of food products (76).

\section{$L A B$ inhibit fungal growth}

Lactic acid bacteria have the ability to control the growth of various fungi. Inhibition of toxigenic fungi has been demonstrated many times over (77-81). Generally, this antagonistic effect is owed to low-molecular-weight compounds produced by the LAB, such as organic acids (acetic and lactic acid), hydrogen peroxide, proteinaceous compounds, reuterin, hydroxyl fatty acids, and phenolic compounds (Table 2). Organic acids can be native to food or added to it. They are products of carbohydrate metabolism and are safe to use for food preservation. Lactic acid lowers $\mathrm{pH}$, which inhibits the growth of various microorganisms or even kills susceptible bacteria (89). In heterofermentation, LAB can produce acetic acid and trace amounts of propionic acid, both of which have a higher content of undissociated forms at a given $\mathrm{pH}$ of the lactic acid. In addition to their effect on the fungus membrane, they also inhibit the absorption of amino acids (89). Low $\mathrm{pH}$ also increases the antifungal activity of various salts of propionic acid (90). A particularly interesting component involved in the inhibition of fungal growth is reuterin, a compound of glycerol fermentation produced by various LAB genera under anaerobic conditions (91). Reuterin suppresses the activity of ribonuclease, the enzyme involved in the biosynthesis of DNA (98). It inhibits the growth of the Fusarium and Aspergillus species. Therefore, to enhance these effects, simply add glycerol to LAB cultures.

Lactic acid bacteria can produce various types of fatty acids that improve the sensory quality of fermented products. One such fatty acid, caproic acid, has a strong antifungal activity. It may be synergistic with propionic, butyric, or valeric acids (92).

The best period of incubation to inhibit the growth of toxin-forming fungi is about $48 \mathrm{~h}$ and the best temperature is from 25 to $30{ }^{\circ} \mathrm{C}(93)$. These conditions favour the production of organic acids, which in turn, inhibit the growth of pathogenic fungi. 
Table 2 Antifungal compounds produced by $L A B$

\begin{tabular}{lcc}
\hline LAB & Compounds & References \\
\hline Lactobacillus reuteri & Reuterin & $(82)$ \\
\hline L. plantarum & Peptids - cyclo (Leu-Pro), cyclo (Phe-Pro) & $(83)$ \\
\hline Pediococcus acidilactici & Phenolic compounds & $(84)$ \\
\hline L. reuteri & Acetic acid, phenyllactic acid & $(85)$ \\
\hline L. plantarum & 3-phenyllactic acid & $(86)$ \\
\hline L. paracasei subsp. paracasei & Lactic acid, propionic acid, acetic acid, succinic acid, \\
hydroxyphenyllactic acid, 3-phenyllactic acid & $(86)$ \\
\hline L. plantarum & 3,6-bis(2-methylpropyl)-2,5-piperazinedion & $(87)$ \\
\hline L. plantarum & 2-hydroxy-4 methylpentanoic acid & $(77)$ \\
\hline
\end{tabular}

Removal of mycotoxins with the $L A B$

Numerous studies have demonstrated that many LAB species can remove mycotoxins. Removal efficiency ranges from small amounts to almost complete removal (94-99). The most efficient species are Lactobacillus rhamnosus, $L$. acidophilus, L. plantarum, L. lactis, Streptococcus thermophilus, and Bifidobacterium bifidum. Each species acts differently and on different mycotoxins. The most versatile seems to be L. rhamnosus, which efficiently removes several mycotoxins at once $(96,100-103)$. Reduction is even higher at $\mathrm{pH} 4$ (100). Other crucial parameters include $\mathrm{LAB}$ cell viability and mycotoxin concentrations (104). There are several mechanisms of removal, but the most efficient is binding to the bacterial cells (105). LAB cell surfaces bind various molecules such as toxins and metal ions $(106,107)$. Their cell walls contain peptidoglycan matrices, neutral polysaccharides, teichoic and lipoteichoic acid, and a protein S layer. However, binding is based on the adsorption capacity of mycotoxins to the cells and not on enzyme activity. This is where peptidoglycan and exopolysaccharides play an important role (108). In fact, thermally inactivated LAB exhibit higher removal capacity, due to changes on the cell surface. Mycotoxin binding is permanent only if the LAB are dead, whereas the living bacteria may release some of the mycotoxin content with time (109). Bueno et al. (110) proposed a mathematical model to illustrate the attachment of $\mathrm{AFB}_{1}$ to $\mathrm{LAB}$ and $S$. cerevisiae, taking into account two processes: adsorption and desorption. This model shows that $\mathrm{AFB}_{1}$ binds to a number of sites in LAB.

Another method of mycotoxin removal is adhesion (111). Its efficiency correlates with the bacterial concentration, but some of the toxin content is released with time and is therefore not permanent.

Table 3 lists the LAB that can remove mycotoxins.

\section{Aflatoxins}

This group of compounds is formed mainly by the species Aspergillus flavus and A. parasiticus, commonly found in soil and in stored agricultural produce (137-139). A. parasiticus often contaminates oilseeds and produces $B_{1}, B_{2}, G_{1}$, and $G_{2}$ aflatoxins $\left(A_{F B}, A_{1} B_{2}, A_{1} G_{1}\right.$, and
$\mathrm{AFG}_{2}$ ), while $A$. flavus is usually found on cereals and produces only the $\mathrm{B}_{1}$ and $\mathrm{B}_{2}$ aflatoxins $(13,18)$ (Table 1$)$. $\mathrm{AFB}_{1}$ in dairy mammal feed is strongly associated with aflatoxin $\mathrm{M}_{1}\left(\mathrm{AFM}_{1}\right)$ in milk (104). Other, less common species include $A$. nomius, $A$. toxicarius, $A$. tamarii, $A$. pseudotamari, and $A$. bombycids $(15,140,141)$.

Conditions favouring aflatoxin production are humidity above $13 \%$ and temperature between 24 and $37^{\circ} \mathrm{C}$ (142), which are mostly encountered in the countries with subtropical and tropical climates (143-145). In recent years, aflatoxins in maize have also been reported in southern Europe. This is probably due to climate change and adaptive abilities of the Aspergillus spp. (146).

Agricultural commodities get contaminated with aflatoxigenic fungi before and at the harvest, processing, transport, and storage (147), especially peanuts, cereals, and their products $(148,149)$, as well as animal feeds $(16$, 150-152).

Motameny et al. (117) investigated the removal of AFB from a gastrointestinal model with $L$. rhamnosus, $L$. plantarum, and L. acidophilus and found that L. plantarum was the most successful (28\%), followed by L. acidophilus (22\%) and L. rhamosus (18\%). Elsanhoty et al. (120) compared the ability of viable and heat-treated $L$. acidophilus, L. rhamnosus, L. sanfranciscensis, and Bifidobacterium angulatum to remove $\mathrm{AFBs}\left(\mathrm{AFB}_{1}, \mathrm{AFB}_{2}\right.$, $\mathrm{AFG}_{1}$, and $\mathrm{AFG}_{2}$ ) from PBS liquid medium. Among the four tested strains, L. rhamnosus was the most efficient in the initial binding of all these aflatoxins and confirmed superior efficiency after 4 washes, which suggests that it forms the most stable complexes with these aflatoxins.

Hernandez-Mendoza et al. (124) studied the binding of $\mathrm{AFB}_{1}$ by Lactobacillus reuteri and $L$. case $i$ at different $\mathrm{pH}$ $(6,7.2$, and 8$)$ and incubation time (0, 4, and $12 \mathrm{~h})$. Both strains showed the highest $\mathrm{AFB}_{1}$-binding capacity at $\mathrm{pH} 7.2$ after 4 and $12 \mathrm{~h}$ of incubation (67.8 and $55.6 \%$ for $L$. case $i$ and 80 and $80 \%$ for L. reuteri, respectively).

Corassin et al. (112) compared the $\mathrm{AFB}_{1}$-binding ability of $L$. delbrueckii spp. bulgaricus, L. rhamnosus, and B. lactis in combination with heat-killed $S$. cerevisiae. This combination ensured complete mycotoxin binding (100\%).

Khoury et al. (113) compared the AFM -binding efficiency of L. bulgaricus and S. thermophilus in PBS. $L$. 
Table 3 The ability of lactic acid bacteria to reduction of mycotoxins

\begin{tabular}{|c|c|c|c|}
\hline Mycotoxins & Bacteria & Matrices & References \\
\hline \multirow{21}{*}{ Aflatoxin } & Lactobacillus bulgaricus & $\begin{array}{l}\text { phosphate buffer saline, skim milk; } \\
\text { UHT skim milk; } \\
\text { milk and yogurt }\end{array}$ & $\begin{array}{l}(94) \\
(112) \\
(113)\end{array}$ \\
\hline & Lactobacillus plantarum & $\begin{array}{l}\text { phosphate buffer saline, skim milk; } \\
\text { silage extract medium; } \\
\text { phosphate buffer saline; } \\
\text { ruminant gastrointestinal model; } \\
\text { maize grain; }\end{array}$ & $\begin{array}{c}(94) \\
(114) \\
(115,116) \\
(117) \\
(118)\end{array}$ \\
\hline & Lactobacillus gasseri & phosphate buffer saline, skim milk & (94) \\
\hline & Lactobacillus rhamnosus & $\begin{array}{c}\text { phosphate buffer saline, skim milk; } \\
\text { UHT skim milk; } \\
\text { silage extract medium; } \\
\text { phosphate buffer saline, dough, baladi bread; } \\
\text { in vitro digestion model; } \\
\text { phosphate buffer saline; } \\
\text { ruminant gastrointestinal model; } \\
\text { MRS broth }\end{array}$ & $\begin{array}{l}(94,119) \\
(112) \\
(114) \\
(120) \\
(121) \\
(122) \\
(117) \\
(100)\end{array}$ \\
\hline & Lactobacillus casei & $\begin{array}{l}\text { phosphate buffer saline; } \\
\text { female rats; } \\
\text { maize grain; } \\
\text { in vitro digestion model; }\end{array}$ & $\begin{array}{c}(115,123,124) \\
(125) \\
(118) \\
(121) \\
\end{array}$ \\
\hline & Lactobacillus fermentum & phosphate buffer saline; & $(115,122)$ \\
\hline & Lactobacillus acidophilus & $\begin{array}{l}\text { in vitro digestion model; } \\
\text { ruminant gastrointestinal model; } \\
\text { maize grain; } \\
\text { phosphate buffer saline, skim milk }\end{array}$ & $\begin{array}{l}(121) \\
(117) \\
(118) \\
(119)\end{array}$ \\
\hline & Lactobacillus brevis & maize grain & (118) \\
\hline & Lactobacillus delbruekki & maize grain & (118) \\
\hline & Lactobacillus reuteri & $\begin{array}{c}\text { female rats; } \\
\text { phosphate buffer saline; } \\
\text { phosphate buffer saline, skim milk }\end{array}$ & $\begin{array}{l}(125) \\
(124) \\
(119)\end{array}$ \\
\hline & Lactobacillus johnsonii & $\begin{array}{l}\text { phosphate buffer saline; } \\
\text { phosphate buffer saline, skim milk }\end{array}$ & $\begin{array}{l}(124) \\
(119)\end{array}$ \\
\hline & Lactobacillus sanfranciscenis & phosphate buffer saline, dough, baladi bread & $(120)$ \\
\hline & Lactococcus lactis & $\begin{array}{c}\text { LAPTg medium; } \\
\text { phosphate buffered saline }\end{array}$ & $\begin{array}{l}(126) \\
(116)\end{array}$ \\
\hline & Streptococcus thermophilus & milk and yogurt & (113) \\
\hline & Enterococcus avium & Phosphate buffer saline, skim milk & (94) \\
\hline & Enterococcus faecium & $\begin{array}{c}\text { LAPTg medium; } \\
\text { phosphate buffer saline }\end{array}$ & $\begin{array}{l}(126) \\
(127)\end{array}$ \\
\hline & Pediococcus pentosaceus & $\begin{array}{l}\text { phosphate buffer saline, skim milk; } \\
\text { phosphate buffer saline }\end{array}$ & $\begin{array}{l}(94) \\
(122)\end{array}$ \\
\hline & Bifidobacterium lactis & $\begin{array}{l}\text { phosphate buffer saline, skim milk; } \\
\text { UHT skim milk }\end{array}$ & $\begin{array}{l}(94) \\
(112)\end{array}$ \\
\hline & Bifidobacterium bifidum & $\begin{array}{c}\text { phosphate buffer saline; } \\
\text { phosphate buffer saline, skim milk }\end{array}$ & $\begin{array}{l}(124) \\
(119)\end{array}$ \\
\hline & Bifidobacterium longum & in vitro digestion model & (121) \\
\hline & Bifidobacterium angulatum & phosphate buffer saline, dough, baladi bread & $(120)$ \\
\hline \multirow{4}{*}{ Ochratoxin A } & Leuconostoc mesenteroides & MRS agar, PDA agar, coffee meal extract agar & $(95)$ \\
\hline & Lactobacillus brevis & MRS agar, PDA agar, coffee meal extract agar & (95) \\
\hline & Lactobacillus plantarum & $\begin{array}{c}\text { sodium phosphate buffer; } \\
\text { MRS agar, PDA agar, coffee meal extract agar }\end{array}$ & $\begin{array}{c}(128) \\
(95)\end{array}$ \\
\hline & Lactobacillus helveticus & MRS medium & $(102)$ \\
\hline
\end{tabular}




\begin{tabular}{|c|c|c|c|}
\hline Mycotoxins & Bacteria & Matrices & References \\
\hline \multirow{23}{*}{ Ochratoxin A } & \multirow{3}{*}{ Lactobacillus bulgaricus } & sodium phosphate buffer; & (128) \\
\hline & & MRS medium; & $(102)$ \\
\hline & & dried skim milk & $(129)$ \\
\hline & \multirow{2}{*}{ Lactobacillus casei } & yeast medium, MRS broth; & $(130)$ \\
\hline & & MRS medium & $(102)$ \\
\hline & \multirow{2}{*}{ Lactobacillus lactis } & sodium phosphate buffer; & $(128)$ \\
\hline & & MRS medium & $(102)$ \\
\hline & \multirow{2}{*}{ Lactobacillus plantarum } & sourdough & $(131)$ \\
\hline & & MRS medium & $(102)$ \\
\hline & \multirow{2}{*}{ Lactobacillus brevis } & sourdough; & $(131)$ \\
\hline & & MRS medium & (102) \\
\hline & Lactobacillus rhamnosus & MRS medium & $(102)$ \\
\hline & Lactobacillus sanfrancisco & sourdough & $(131)$ \\
\hline & Lactobacillus sanfransciscensis & MRS medium & $(102)$ \\
\hline & Lactobacillus sakei & yeast medium, MRS broth & (130) \\
\hline & \multirow{2}{*}{ Lactobacillus acidophillus } & sodium phosphate buffer; & $(128)$ \\
\hline & & MRS medium & $(102)$ \\
\hline & Oenococcus oeni & MLO culture medium & (132) \\
\hline & $\begin{array}{c}\text { Streptococcus salivarius subsp. } \\
\text { thermophilus }\end{array}$ & dried skim milk & $(129)$ \\
\hline & Streptococcus salivarius & yeast medium, MRS broth & (130) \\
\hline & Bifidobacterium bifidum & dried skim milk & $(129)$ \\
\hline & Bifidobacterium longum & sodium phosphate buffer & $(128)$ \\
\hline & Bifidobacterium animalis & sodium phosphate buffer & (128) \\
\hline \multirow{7}{*}{ Fumonisins } & Lactobacillus paraplantarum & corn infusion & (133) \\
\hline & Lactobacillus lactis & corn infusion & $(96)$ \\
\hline & Lactobacillus bulgaricus & corn infusion & (96) \\
\hline & Lactobacillus rhamnosus & corn infusion & $(96)$ \\
\hline & Lactococcus lactis subsp. cremoris & corn infusion & $(133)$ \\
\hline & Leuconostoc mesenteroides & corn infusion & $(96)$ \\
\hline & Streptococcus thermophilus & corn infusion & $(133)$ \\
\hline \multirow{4}{*}{ Zearalenon } & Lactobacillus paracasei & phosphate buffer saline, mice & (97) \\
\hline & Lactobacillus plantarum & $\begin{array}{c}\text { phosphate buffer saline, mice; } \\
\text { silage extract medium }\end{array}$ & $\begin{array}{l}(97) \\
(114)\end{array}$ \\
\hline & Lactobacillus rhamnosus & phosphate buffer saline & $(102,134)$ \\
\hline & Streptococcus thermophilus & ruminal fluid & $(135)$ \\
\hline \multirow{6}{*}{ Trichotecenes } & Lactobacillus plantarum & MRS broth & $(98)$ \\
\hline & Lactobacillus pentosus & ultrapure water & $(104)$ \\
\hline & Lactobacillus paracasei & ultrapure water & $(104)$ \\
\hline & Lactobacillus casei & MRS broth & $(98)$ \\
\hline & Lactobacillus brevis & MRS broth & (98) \\
\hline & Lactococcus lactis & MRS broth & (98) \\
\hline \multirow{8}{*}{ Patulin } & Lactobacillus rhamnosus & $\begin{array}{c}\text { apple juice; } \\
\text { phosphate buffer saline }\end{array}$ & $\begin{array}{l}(103) \\
(136)\end{array}$ \\
\hline & Lactobacillus acidophilus & MRS broth & (99) \\
\hline & Lactobacillus delbrueckii ssp. & phosphate buffer saline; & $\begin{array}{l}(136) \\
(99)\end{array}$ \\
\hline & $\begin{array}{c}\text { Lactis } \\
\text { Lactobacillus plantarum }\end{array}$ & $\begin{array}{l}\text { MRS broth } \\
\text { MRS broth }\end{array}$ & $\begin{array}{l}(99) \\
(99)\end{array}$ \\
\hline & \multirow{2}{*}{ Enterococcus faecium } & apple juice; & (103) \\
\hline & & phosphate buffer saline & (127) \\
\hline & Bifidobacterium bifidum & phosphate buffer saline & (136) \\
\hline & Bifidobacterium animalis & phosphate buffer saline & (136) \\
\hline
\end{tabular}


bulgaricus showed the highest binding efficiency (87.6\%). The same species was also used to investigate its AFM binding in yogurt processing over $6 \mathrm{~h}$. Again, L. bulgaricus won with $58.5 \%$, over $S$. thermophilus which bound $37.7 \%$ of $\mathrm{AFM}_{1}$. It was also found that the binding efficiency increased with time.

Sezer et al. (116) investigated the efficiency of LAB $(L$. lactis and L. plantarum) and their bacteriocins in removing $\mathrm{AFB}_{1}$ from liquid culture. L. plantarum was more efficient than L. lactis ( $46 \%$ vs $27 \%$, respectively), but efficacy was even higher when combined with bacteriocins. When the two strains were combined, $\mathrm{AFB}_{1}$ removal reached $81 \%$.

Zinedine et al. (100) studied LAB efficiency in removing $\mathrm{AFB}_{1}$ from the Moroccan sourdough bread. The winner was L. rhamnosus with $44.89 \% \mathrm{AFB}_{1}$ removal at pH 6.5 and $30{ }^{\circ} \mathrm{C}$.

\section{Ochratoxin A}

There are three major OTA-producing species, Aspergillus ochraceus, A. carbonarius, and Penicillium verrucosum $(153,154)$. Other species reported to produce OTA include A. niger, A. sclerotioniger, A. lacticoffeatus, A. foetidus, A. westerdijkiae, A. steynii and A. tubingensis $(155,156)$

OTA is common in stored cereal grain, starch-rich food such as cereals (including wheat, barley, maize, rice, oat, and rye), and edible legume seeds (20). It does not attack plants during vegetation, save for the grapevines (23) (Table 1).

A number of studies investigated its removal by LAB (95, 102, 128-130, 132). Piotrowska and Żakowska (102) reported removal by L. rhamnosus as high as $87.5 \%$. L . acidophilus removed $70.5 \%$, L. lactis $59.6 \%$, L. brevis $56.2 \%$, L. plantarum $56.2 \%$, L. sanfranciscensis $52.0 \%$, L. helveticus (31.0\%), L. delbrueckii subsp. bulgaricus $28.3 \%$, and $L$. casei $16.6 \%$. In another study, Piotrowska and Żakowska (131) investigated OTA removal from flour. L. plantarum was the most efficient (56\% removal), followed by $L$. sanfrancisco $(51.0 \%)$. A combination of $L$. plantarum, L. sanfrancisco, L. brevis, and S. cerevisiae, however, yielded even higher removal of $68 \%$ after $40 \mathrm{~h}$ of incubation.

Fuchs et al. (128) examined the reactions and the relationship between the amount of added mycotoxins (500 and $1000 \mathrm{ng}$ ) and LAB species in a liquid medium. Even though they did not establish a clear relationship, the most efficient in removing OTA was L. acidophilus (97\%), followed by Bifidobacterium longum (58\%), L. plantarum (44\%), L. lactis (34\%), L. casei (31\%), and L. bulgaricus $(29 \%)$

Mateo et al. (132) tested three factors to investigate the dynamics of OTA removal: Oenococcus oeni (10 strains), OTA level in medium ( 2 and $5 \mu \mathrm{g} \mathrm{L}^{-1}$ ), and incubation time $(0,5,10$, and 14 days $)$. All ten strains eliminated OTA from the medium but the highest reduction was $63 \%$ after 14 days of incubation with the $124 \mathrm{M}$ strain in a medium spiked with $2 \mu \mathrm{g} \mathrm{L}^{-1}$ of OTA and $58 \%$ after 10 days of incubation with the $6 \mathrm{G}$ strain in a medium spiked with $5 \mu \mathrm{g} \mathrm{L}^{-1}$ of OTA.

In another experiment Kapetanakou et al. (130) used Streptococcus salivarius, Lactobacillus sakei, and L. casei to reduce varying amounts of OTA, taking into account $\mathrm{pH}$. Reduction increased slightly with the amount of added mycotoxins. The highest removal of $20 \%$ was observed for the two Lactobacillus species at $\mathrm{pH} 5$. The best result for S. salivarius was about $10 \%$ at $\mathrm{pH} 4$.

\section{Fumonisins}

Fumonisins have been identified and described relatively recently. They were first isolated from the strain Fusarium verticillioides (formerly F. moniliforme) in 1988 in South Africa (158). Other producers of fumonisins are F. proliferatum, F. napiforme, F. oxysporum, F. dlamini, F. nygamai, and Aspergillus niger (which produce fumonisins $\mathrm{B}_{2}, \mathrm{~B}_{4}$, and $\mathrm{B}_{6}$ but not $\left.\mathrm{B}_{1}\right)(44,159-161)$.

Of the 28 fumonisin analogues, only three are natural contaminants of food and feed: $\mathrm{FB}_{1}$ (which makes 70-80\% of the three fumonisins), $\mathrm{FB}_{2}(15-25 \%)$, and $\mathrm{FB}_{3}(3-8 \%)$ (162) Fumonisins typically contaminate maize crops, but were also reported in other cereals (42) and asparagus (163) (Table 1).

Niderkorn et al. (96) tested the ability of several bacterial species to remove $\mathrm{FB}_{1}$ and $\mathrm{FB}_{2}$ from a medium at $\mathrm{pH} 4$. FB was best removed by Leuconostoc mesenteroides (82 \%), Pediococcus pentosaceus (79\%), L. plantarum (74\%), and L. rhamnosus (74\%). FB 2 was completely (100\%) removed by L. lactis, whereas L. mesenteroides, S. thermophilus, P. pentosaceus, L. casei, L. helveticus, $L$. bulgaricus, L. plantarum, and L. rhamnosus removed over $90 \%$. Niderkorn et al. (133) also combined L. paraplantarum, S. thermophilus, and various treatment methods to eliminate $\mathrm{FB}_{1}$ and $\mathrm{FB}_{2}$. The best binding result (37\%) was observed with $S$. thermophilus in trichloroetic acid. Under the same conditions L. paraplantarum bound $19 \%$ of the mycotoxin. With $\mathrm{HCl}$ S. thermophilus bound $24 \%$. Binding with other treatments did not exceed $15 \%$. FB binding rate was much higher than that of $\mathrm{FB}_{1}$, and the highest was observed with trichloroacetic acid ( $76 \%$ for $S$. thermophilus and $65 \%$ for L. paraplantarum) and $\mathrm{HCl}$ (65\% for S. thermophilus and $51 \%$ for L. paraplantarum). These findings indicate that the method of detoxification, $\mathrm{pH}$, and bacterial concentration play the key role in fumonisin removal. Methods that degrade cell wall surface structures increase the mycotoxin binding area. Binding can be further improved by increasing the concentration of peptidoglycans.

\section{Zearalenone}

Zearalenone (ZEA), also known as the F-2 toxin, is the third most common mycotoxin in plants, maize in particular $(1,26,35)$. It is one of the strongest non-steroid oestrogens found in nature (164) produced by certain Fusarium species, 
mainly $F$. graminearum, $F$. culmorum, $F$. semitectum, $F$. equiseti, and $F$. cerealis $(32,165,166)$. Fusaria are among the most pathogenic toxin-forming fungi. Unlike other mycotoxins, ZEA reaches its maximum levels at $16 \%$ humidity and temperature below $25^{\circ} \mathrm{C}(167)$, usually before harvest. High levels were also detected in animal feed containing improperly stored maize $(26,32)$. Apart from maize, zearalenone can contaminate wheat, barley, oat, sorghum, rice, and peas $(26,38,39,40)$ (Table 1).

El-Nezami et al. (134) tested ZEA removal from culturing media with $L$. rhamnosus. In one experiment, it was about $60 \%$ and in another (102) $64 \%$ from phosphate buffer and lipase with heat-killed bacteria. Acid-killed bacteria removed $59 \%$ of the mycotoxin.

Niderkorn et al. (135) tested the ability of $S$. thermophilus to bind ZEA and its metabolites ( $\alpha$ - and $\beta$-ZOL) in ruminal fluid. Feed (50\% maize grain and $50 \%$ alfalfa hay) alone bound $73 \%$ of ZEA and its metabolites almost immediately and $69 \%$ after $18 \mathrm{~h}$. When $S$. thermophilus was added to the feed, binding rose to $91 \%$ at first and dropped to $67 \%$ after $18 \mathrm{~h}$. When feed was eliminated as an experimental factor, S. thermophilus alone bound $83 \%$ and $46 \%$ of ZEA and its metabolites, respectively.

In another study (168), L. plantarum was combined with the Tunisian montmorillonite clay as absorbent. Clay alone bound $87 \%$, of ZEA, L. plantarum alone bound $78 \%$, while the combination bound as much as $94 \%$ after $24 \mathrm{~h}$.

Čvek et al. (111) reported that ZEA binding rose with LAB concentrations in MRS agar (99.12\% for L. plantarum and $84.71 \%$ for L. rhamnosus at the concentration of 8 $\left.\log _{10} \mathrm{CFU} \mathrm{mL} \mathrm{mL}^{-1}\right)$ and dropped with incubation time (60-70\% after $72 \mathrm{~h}$ ).

\section{Trichothecenes}

Fungi producing trichothecenes B (deoxynivalenol and its derivatives as well as nivalenol) mostly affect wheat and other crops (169). They include Fusarium culmorum and $F$. graminearum, which are also responsible for the biosynthesis of ZEA $(1,26,170)$. Conditions favouring trichothecenes production are $21-25^{\circ} \mathrm{C}$ and $>0.95 \%$ water activity, depending on Fusarium species $(32,171)$.

The primary sources of deoxynivalenol (DON) in the food chain are cereals, including wheat, barley, maize, and oat $(2,25-27,30-33)$. It was also found in buckwheat, sorghum, and processed food such as flour, bread, pasta, beer, and malt $(29,34)$ (Table 1).

Franco et al. (104) investigated its removal by $L$. plantarum, L. pentosus, and L. paracasei. The study was conducted in three variants; (i) with viable cells, (ii) with pasteurised cells, and (iii) with sterilised cells. Sterilised unviable cells showed the best results when used alone; $L$ plantarum bound $67 \%$ of the toxin, L. pentosus $47 \%$, and L. paracasei $57 \%$.

Zou et al. (98) investigated the removal of DON and T-2 from MRS agar with L. lactis, L. brevis, L. casei, and
L. plantarum over $0,24,48$, and $72 \mathrm{~h}$ of incubation. The best results were observed at $48 \mathrm{~h}$, while at $72 \mathrm{~h}$ the binding rate did not change. L. plantarum was the most successful in reducing both DON and T-2 levels (from 1 to about $\left.0.8 \mu \mathrm{g} \mathrm{mL}^{-1}\right)$.

\section{Patulin}

Patulin is the best known mycotoxin, toxic to both plants and animals and associated with fruit and fruit preserves (45-47). It was first isolated from Penicillium patulum in 1940. The Joint Food and Agriculture Organization - World Health Organization Expert Committee on Food Additives has limited the maximum tolerable daily intake of this mycotoxin to $<0.4 \mathrm{mg} \mathrm{kg}^{-1}$ of body weight per day.

Patulin is a dangerous mycotoxin produced under improper storage conditions of various products. Therefore, numerous studies have been conducted to reduce it. Hatab et al. (136) tested the efficiency of viable and unviable Bifidobacterium bifidum, B. animalis, L. rhamnosus, and L. lactis at $37^{\circ} \mathrm{C}$ for $24 \mathrm{~h}$ varying the $\mathrm{pH}$. The best results were obtained at $\mathrm{pH} 4$ with unviable bacteria, as follows (in the descending order): B. bifidum $(54.8 \%)$, L. rhamnosus (52\%), L. lactis $(35.6 \%)$, and B. animalis $(21.3 \%)$. The same authors (103) also investigated the efficiency of $L$. lactis, L. rhamnosus, L. helveticus, B. animails, B. bifidum, and Enterococcus faecium in patulin reduction in apple juice varying two factors: temperature $\left(30\right.$ and $\left.37^{\circ} \mathrm{C}\right)$ and patulin concentrations $\left(100,150\right.$, and $\left.200 \mu \mathrm{g} \mathrm{mL}^{-1}\right)$. The most efficient reduction (about $80 \%$ ) was observed with L. rhamnosus (strain 6224) at patulin concentration of $100 \mu \mathrm{g} \mathrm{mL} \mathrm{H}^{-1}$ and temperature of $30^{\circ} \mathrm{C}$.

Hawar et al. (99) reported the highest reduction rate from 100 to about $50 \mu \mathrm{g} \mathrm{mL}^{-1}$ at $\mathrm{pH} 2$ and the lowest at $\mathrm{pH} 9$ (to about $85 \mu \mathrm{g} \mathrm{mL}^{-1}$ ). They also found that the reduction rate dropped with higher $\mathrm{CFU}$.

\section{CONCLUSIONS}

Many studies have demonstrated varying efficiency of $\mathrm{LAB}$ in removing mycotoxins from a variety of matrices. Removal mainly relies on mycotoxin binding to LAB cells and inactivation by antifungal products such as acetic acid.

Rendering LAB cells unviable with high temperature or acids seems to increase their mycotoxin-binding efficiency. This is quite likely related to the LAB cell wall components, mainly peptidoglycans and exopolysaccharides. The binding mechanisms, however, are not yet fully understood, and remain to be investigated by future research.

The most efficient LAB strains could be applied in various cereal products and livestock feed to increase food safety. Washing the products with suitable LAB preparations could also bind and remove mycotoxins. Preparations could also be used in cases of fungal infection in animals. Livestock may be fed these compounds at an early stage of 
fungal infection, as they not only provide nutrients but also act as pharmaceuticals.

Despite the promising research findings, several questions need to be answered by future tests. As raw materials are subjected to ever more complex technological processes to meet consumer requirements, these questions include optimal timing, $\mathrm{pH}$, methods for inactivating bacterial cells, and LAB concentrations that would yield best results. Future studies should also focus on identifying the exact mechanisms of mycotoxin binding to render it permanent. In the future, LAB will be used more widely in processing raw food liable to contamination with mycotoxins. At this stage, reducing mycotoxins in practice seems like a challenge to be addressed by new technological schemes.

\section{REFERENCES}

1. Goliński, P., Waśkiewicz, A., Gromadzka, K. Mycotoxins and mycotoxicoses under climatic conditions of Poland. Polish J Vet Sci 2009;12:581-8. PMID: 20169938

2. Antonissen G, Martel A, Pasmans F, Ducatelle R, Verbrugghe E, Vandenbroucke V, Li S, Haesebrouck F, van Immerseel F, Croubels S. The impact of Fusarium mycotoxins on human and animal host susceptibility to infectious diseases. Toxins (Basel) 2014;6:430-52. doi: 10.3390/toxins6020430

3. Bhatnagar D, Yu J, Ehrlich KC. Toxins of filamentous fungi. Chem Immunol 2002;81:167-206. doi: 10.1159/000058867

4. Marin S, Ramos AJ, Cano-Sancho G, Sanchis V. Mycotoxins: Occurrence, toxicology, and exposure assessment. Food Chem Toxicol 2013;60:218-37. doi: 10.1016/j.fct.2013.07.04

5. Adeyeye SAO. Fungal mycotoxins in foods: A review. Cogent Food Agric 2016;2:1213127. doi: $10.1080 / 23311932.2016 .1213127$

6. Tola M, Kebede B. Occurrence, importance and control of mycotoxins: A review. Cogent Food Agric 2016;2:1191103. doi: $10.1080 / 23311932.2016 .1191103$

7. Bryden WL. Mycotoxin contamination of the feed supply chain: implications for animal productivity and feed security. Animal Feed Sci Technol 2012;173:134-58. doi: 10.1016/j. anifeedsci.2011.12.014

8. Han Z, Nie D, Ediage EN, Yang X, Wang J, Chen B, Li S, On SL, De Saeger S, Wu A. Cumulative health risk assessment of co-occurring mycotoxins of deoxynivalenol and its acetyl derivatives in wheat and maize: case study, Shanghai, China. Food Chem Toxicol 2014;74:334-42. doi: 10.1016/j.fct.2014.10.018

9. Bennett JW, Klich M. Mycotoxins. Clin Microbiol Rev 2003;16:497-516. doi: 10.1128/CMR.16.3.497-516.2003

10. Calado T, Venancio A, Abrunhosa L. Irradiation for mold and mycotoxin control: a review. Compr Rev Food Sci Food Saf 2014;13:1049-61. doi: 10.1111/1541-4337.12095

11. de Nijs M, Mengelers MJB, Boon PE, Heyndrickx E, Hoogenboom LAP, Lopez P, Mol HGJ. Strategies for estimating human exposure to mycotoxins via food. World Mycotoxin J 2016;9:831-45. doi: 10.3920/WMJ2016.2045

12. Gnonlonfin GJB, Adjovi YC, Tokpo AF, Agbekponouc ED, Ameyapohc Y, de Souzac C, Brimerd L, Sannib A. Mycobiota and identification of aflatoxin gene cluster in marketed spices in West Africa. Food Control 2013;34:115-20. doi: 10.1016/j. foodcont.2013.04.021

13. Iqbal SA, Khalil IA, Shah H. Aflatoxin contents of stored and artificially inoculated cereals and nuts. Food Chem 2006;98:699-703. doi: 10.1016/j.foodchem.2005.06.034

14. Lewis L, Onsongo M, Njapau H. Aflatoxin contamination of commercial maize products during an outbreak of acute aflatoxicosis in eastern and central Kenya. Environ Health Perspect 2005;113:1763-7. doi: 10.1289/ehp.7998

15. Mushtaq M, Sultana B, Anwar F, Khan MZ, Ashrafuzzaman M. Occurrence of aflatoxins in selected processed foods from Pakistan. Int J Mol Sci 2012;13:8324-37. doi: 10.3390/ ijms13078324

16. Offiah N, Adesiyun A. Occurrence of aflatoxins in peanuts, milk, and animal feed in Trinidad. J Food Prot 2007;70:7715. doi: 10.4315/0362-028X-70.3.771

17. Ratnavathi CV, Komala VV, Kumar BS, Das IK, Patil JV. Natural occurrence of aflatoxin $B_{1}$ in sorghum grown in different geographical regions of India. J Sci Food Agric 2012;92:2416-20. doi: 10.1002/jsfa.5646

18. Romagnoli B, Menna V, Gruppioni N, Bergamini C. Aflatoxins in spices, aromatic herbs, herb-teas and medicinal plants marketed in Italy. Food Control 2007;18:697-701. doi: 10.1016/j.foodcont.2006.02.020

19. Fazekas B, Tar AK, Zomborszky-Kovács M. Ochratoxin a contamination of cereal grains and coffee in Hungary in the year 2001. Acta Vet Hung 2002;50:177-88. doi: 10.1556/ AVet.50.2002.2.7

20. Llorent-Martínez EJ, Ortega-Barrales P, Fernández-de Córdova ML, Ruiz-Medina A. Quantitation of ochratoxin a in cereals and feedstuff using sequential injection analysis with luminescence detection. Food Control 2013;30:379-85. doi: 10.1016/j.foodcont.2012.07.036

21. Meucci V, Costa E, Razzuoli E. Occurrence of ochratoxin A in blood of Italian slaughtered pigs. Toxicol Lett 2005:158(1 Suppl):S116.

22. Terra MF, Prado G, Pereira GE, Ematné HJ, Batista LR. Detection of ochratoxin A in tropical wine and grape juice from Brazil. J Sci Food Agric 2013;93:890-4. doi: 10.1002/ jsfa. 5817

23. Varga J, Kozakiewicz Z. Ochratoxin A in grapes and grapederived products. Trends Food Sci Technol 2006;17:72-81. doi: $10.1016 / j . t i f s .2005 .10 .007$

24. Aniołowska M, Steininger M. Determination of trichothecenes and zearalenone in different corn (Zea mays) cultivars for human consumption in Poland. J Food Composit Anal 2014;33:14-9. doi: 10.1016/j.jfca.2013.09.008

25. dos Santos JS, Souza TM, Ono EYS, Hashimoto EH, Bassoi MC, de Mirande MZ, Itano EN, Kawamura O, Hirooka EY. Natural occurrence of deoxynivalenol in wheat from Paraná State, Brazil and estimated daily intake by wheat products. Food Chem 2013;138:90-5. doi: 10.1016/j. foodchem.2012.09.100

26. Goliński P, Waśkiewicz A, Wiśniewska H, Kiecana I, Mielniczuk E, Gromadzka K, Kostecki M, Bocianowski J, Rymaniak E. Reaction of winter wheat (Triticum aestivum L.) cultivars to infection with Fusarium spp.: mycotoxin contamination in grain and chaff. Food Addit Contam Part A Chem Anal Control Expo Risk Assess 2010;27:1015-24. doi: 10.1080/19440041003702208

27. Gonzalez Pereyra ML, Pereyra CM, Ramirez ML, Rosa CAR, Dalcero AM, Cavaglieri LR. Determination of mycobiota 
and mycotoxins in pig feed in central Argentina. Lett Appl M i crobiol 2008;46:555-61. doi : 10.1111/j.1472-765X.2008.02347.x

28. Montes R, Segarra R, Castillo MA. Trichothecenes in breakfast cereals from the Spanish retail market. J Food Compost Anal 2012;27:38-44. doi: 10.1016/j.jfca.2012.05.004

29. Pacin A, Ciancio Bovier E, Cano G, Taglieri D, Pezzani HC. Effect of the bread making process on wheat flour contaminated by deoxynivalenol and exposure estimate. Food Control 2010;21:492-5. doi: 10.1016/j.foodcont.2009.07.012

30. Sampietro DA, Fauguel CM, Vattuone MA, Presello DA, Catalan CAN. Phenylpropanoids from maize pericarp: resistance factors to kernel infection and fumonisin accumulation by Fusarium verticillioides. Eur J Plant Pathol 2013;135:105-13. doi: 10.1007/s10658-012-0069-3

31. Tajehmiri A, Aliabadi MA, Darsanaki RK. Occurrence of deoxynivalenol in cereals and cereal based products: a short review. Scientific J Biol Sci 2014;3:1-5.

32. Wiśniewska H, Stępień $Ł$, Waśkiewicz A, Beszterda M, Góral T, Belter J. Toxigenic Fusarium species infecting wheat heads in Poland. Cent Eur J Biol 2014;9:163-72. doi: 10.2478/ s11535-013-0262-1

33. Yazar S, Omurtag GZ. Fumonisins, trichothecenes and zearalenone in cereals. Int J Mol Sci 2008;9:2062-90. doi: 10.3390/ijms9112062

34. Yazdanpanah H, Shafaati A, Foroutan SM, Zarghi A, AboulFathi F, Khoddam A, Shaki F, Nazari F. Occurrence of deoxynivalenol in foods for human consumption from Tehran, Iran. Iran J Pharmaceut Res 2014;13(Suppl):87-92. PMCID: PMC3977057

35. Cano-Sancho G, Marin S, Ramos AJ, Sanchis V. Occurrence of zearalenone, an oestrogenic mycotoxin, in Catalonia (Spain) and exposure assessment. Food Chem Toxicol 2012;50:835-9. doi: 10.1016/j.fct.2011.11.049

36. Döll S, Dänicke S. The Fusarium toxins deoxynivalenol (DON) and zearalenone (ZON) in animal feeding. Prev Vet Med 2011;102:132-45. doi: 10.1016/j.prevetmed.2011.04.008

37. Hewitt TC, Flack CL, Kolodziejczyk JK, Chacon AM, D'Ovidio KL. Occurrence of zearalenone in fresh corn and corn products collected from local Hispanic markets in San Diego County, CA. Food Control 2012;26:300-4. doi: 10.1016/j.foodcont.2012.01.035

38. Seeling K, Dänicke S. Relevance of the Fusarium toxins deoxynivalenol and zearalenone in ruminant nutrition. A review. J Anim Feed Sci 2005;14:3-40. doi: 10.22358/ jafs/66965/2005

39. Streit E, Schatzmayr G, Tassis P, Tzika E, Marin D, Taranu I, Tabuc C, Nicolau A, Aprodu I, Puel O, Oswald IP. Current situation of mycotoxin contamination and co-occurrence in animal feed-focus on Europe. Toxins (Basel) 2012;4:788-809. doi: $10.3390 /$ toxins 410078

40. Waśkiewicz A, Gromadzka K, Wiśniewska H, Goliński P. Accumulation of zearalenone in genotypes of spring whea after inoculation with Fusarium culmorum. Cereal Res Commun 2008;36(Suppl 6):401-4.

41. Feng YZ, Lu XH, Tao B, Pang MH, Liu YC, Dong JG. Natural occurrence of fumonisins $\mathrm{B}_{1}$ and $\mathrm{B}_{2}$ in corn from three main production provinces in China. J Food Prot 2011;8:1374-8. doi: 10.4315/0362-028X.JFP-11-103

42. Ghiasian SA, Rezayat SM, Kord-Bacheh P, Maghsood AH, Yazdanpanah H, Shephard GS, van der Westhuizen L, Vismer HF, Marasas WFO. Fumonisin production by Fusarium species isolated from freshly harvested corn in Iran. Mycopathologia 2005;159:31-40. doi: 10.1007/s11046-0043899-5

43. Martins FA, Ferreira FMD, Ferreira FD, Bando E, Nerilo SB, Hirooka EY, Machinski Jr M. Daily intake estimates of fumonisins in corn-based food products in the population of Parana, Brazil. Food Control 2012;26:614-8. doi: 10.1016/j. foodcont.2012.02.019

44. Waśkiewicz A, Stępień $Ł$, Wilman K, Kachlicki P. Diversity of pea-associated $F$. proliferatum and $F$. verticillioides populations revealed by $F U M 1$ sequence analysis and fumonisin biosynthesis. Toxins (Basel) 2013;5:488-503. doi: $10.3390 /$ toxins 5030488

45. Beltran E, Ibanez M, Sancho VJ, Hernández F. Determination of patulin in apple and derived products by UHPLC-MS/MS. Study of matrix effects with atmospheric pressure ionisation sources. Food Chem 2014;142:400-7. doi: 10.1016/j. foodchem.2013.07.069

46. Bragulat MR, Abarca ML, Cabañes FJ. Low occurrence of patulin- and citrinin-producing species isolated from grapes. Lett Appl Microbiol 2008;47:286-9. doi: 10.1111/j.1472-765X.2008.02422.X

47. Marin S, Mateo EM, Sanchis V, Valle-Algarra FM, Ramos AJ, Jiménez M. Patulin contamination in fruit derivatives, including baby food, from the Spanish market. Food Chem 2011;124:563-8. doi: 10.1016/j.foodchem.2010.06.072

48. Zain ME. Impact of mycotoxins on humans and animals. J Saudi Chem Soc 2011;15:129-44. doi: 10.1016/j. jscs.2010.06.006

49. Hussein HS, Brasel JM. Toxicity, metabolism, and impact of mycotoxins on humans and animals. Toxicology 2001;167:101-34. doi: 10.1016/S0300-483X(01)00471-1

50. Assunção R, Silva MJ, Alvito P. Challenges in risk assessment of multiple mycotoxins in food. World Mycotoxin J 2016;9:791-811. doi: 10.3920/WMJ2016.2039

51. Pierron A, Alassane-Kpembi I, Oswald IP. Impact of mycotoxin on immune response and consequences for pig health. Anim Nutr 2016;2:63-8. doi: 10.1016/j. aninu.2016.03.001

52. Magan N, Aldred D, Mylona K, Lambert RJ. Limiting mycotoxins in stored wheat. Food Addit Contam Part A Chem Anal Control Expo Risk Assess 2010;27:644-50. doi: 10.1080/19440040903514523

53. Magan N, Aldred D. Post-harvest control strategies: minimizing mycotoxins in the food chain. Int J Food Microbiol 2007;119:131-9. doi: 10.1016/j. ijfoodmicro.2007.07.034

54. Kabak B, Dobson ADW. Biological strategies to counteract the effects of mycotoxins. J Food Prot 2009;72:2006-16. doi: 10.4315/0362-028X-72.9.2006

55. Kabak B, Dobson AD, Var I. Strategies to prevent mycotoxin contamination of food and animal feed: a review. Crit Rev Food Sci Nutr 2006;46:593-619. doi: 10.1080/10408390500436185

56. Karlovsky P, Suman M, Berthiller F, De Meester J, Eisenbrand G, Perrin I, Oswald IP, Speijers G, Chiodini A, Recker T, Dussort P. Impact of food processing and detoxification treatments on mycotoxin contamination. Mycotoxin Res 2016;32:179-205. DOI: 10.1007/s12550016-0257-7 
57. Ji C, Fan Y, Zhao L. Review on biological degradation of mycotoxins. Anim Nutr 2016;2:127-33. doi: 10.1016/j. aninu.2016.07.003

58. Tsitisigiannis DI, Dimakopoulou M, Antoniou PP, Tjamos EC. Biological control strategies of mycotoxigenic fungi and associated mycotoxins in Mediterranean basin crops Phytopathol Mediterr 2012;51:158-74. doi: 10.14601/ Phytopathol Mediterr-9497

59. Inan F, Pala $\bar{M}$, Doymaz I. Use of ozone in detoxification of aflatoxin $B_{1}$ in red pepper. J Stored Prod Res 2007;43:425-9. doi: 10.1016/j.jspr.2006.11.004

60. McKenzie KS, Sarr AB, Mayura K, Bailey RH, Miller DR, Rogers TD, Norred WP, Voss KA, Plattner RD, Kubena LF, Phillips TD. Oxidative degradation and detoxification of mycotoxins using a novel source of ozone. Food Chem Toxicol 1997;35:807-20. PMID: 9350226

61. McDonough MX, Campabadal CA, Mason LJ, Maier DE, Denvir A, Woloshuk C. Ozone application in a modified screw conveyor to treat grain for insect pests, fungal contaminants, and mycotoxins. J Stored Prod Res 2011;47:249-54. doi: 10.1016/j.jspr.2011.04.001

62. de Alencar ER, Faroni LRD, Soares NFF, da Silva WA, da Silva Carvalho MC. Efficacy of ozone as a fungicidal and detoxifying agent of aflatoxins in peanuts. J Sci Food Agric 2012;92:899-905. doi: 10.1002/jsfa.466

63. Fouler SG, Trivedi AB, Kitabatake N. Detoxification of citrinin 74 and ochratoxin A by hydrogen peroxide. J AOAC Int 1994;77:631-7. PMID: 8012212

64. di Stefano V, Pitonzo R, Avellone G. Effect of gamma irradiation on aflatoxins and ochratoxin a reduction in almond samples. J Food Res 2014;3:113-8. doi: 10.5539/jfr.v3n4p113

65. Ghanem I, Orfi M, Shamma M. Effect of gamma radiation on the inactivation of aflatoxin $\mathrm{B}_{1}$ in food and feed crops. Braz J Microbiol 2008;39:787-91. doi: 10.1590/S1517838220080004000035

66. Weng CY, Martinez AJ, Park DL. Efficacy and permanency of ammonia treatment in reducing aflatoxin levels in corn. Food Addit Contam 1994;11:649-58. doi: 10.1080/02652039409374266

67. Oliveira G, da Silva DM, Pereira RGFA, Paiva LC, Prado G, Batista LR. Effect of different roasting levels and particle sizes on ochratoxin a concentration in coffee beans. Food Control 2013;34:651-6. doi: 10.1016/j.foodcont.2013.06.014

68. Bittner A, Cramer B, Harrer H, Humpf H-U. Structure elucidation and in vitro cytotoxicity of ochratoxin alpha amide, a new degradation product of ochratoxin A. Mycotoxin Res 2015;31:83-90. doi: 10.1007/s12550-0140218-y

69. Rempe I, Kersten S, Valenta H, Dänicke S. Hydrothermal treatment of naturally contaminated maize in the presence of sodium metabisulfite, methylamine and calcium hydroxide; effects on the concentration of zearalenone and deoxynivalenol. Mycotoxin Res 2013;29:169-75. doi: 10.1007/s12550-013-0166-y

70. Kandler O. Carbohydrate metabolism in lactic acid bacteria Antonie van Leeuwenhoek 1983;49:209-24. PMID: 6354079

71. Stiles ME, Holzapfel WH. Lactic acid bacteria of foods and their current taxonomy. Int J Food Microbiol 1997;36:1-29. doi: 10.1016/S0168-1605(96)01233-0

72. Miller N, Wetterstrom W. The beginnings of agriculture: The ancient near east and north Africa. In: Kiple K, Ornelas K, editors. The Cambridge World History of Food. Vol 2. Cambridge (UK): Cambridge Univ Press; 2000. p. 1123-39.

73. Nuraida L. A review: Health promoting lactic acid bacteria in traditional Indonesian fermented foods. Food Sci Human Wellness 2015;4:47-55. doi: 10.1016/j.fshw.2015.06.001

74. Wood B. Microbiology of Fermented Foods. London: Blackie; 1998.

75. Zannini E, Waters DM, Coffey A, Arendt EK. Production, properties, and industrial food application of lactic acid bacteria-derived exopolysaccharides. Appl Microbiol Biotechnol 2016;100:1121-35. doi: 10.1007/s00253-015$7172-2$

76. Indira K. Jayalakshmi S, Gopalakrishnan A, Srinivasan M. Biopreservative potential of marine Lactobacillus spp. Afr J Microbiol Res 2011;5:2287-96.

77. Ndagano D, Lamoureux T, Dortu C, Vandermoten S, Thonart P. Antifungal activity of 2 lactic acid bacteria of the Weissella genus isolated from food. J Food Sci 2011;76:M305-11. doi: 10.1111/j.1750-3841.2011.02257.x

78. Gerez CL, Carbajo MS, Rollán G, Torres Leal G, Font de Valdez $\mathrm{G}$. Inhibition of citrus fungal pathogens by using lactic acid bacteria. J Food Sci 2010;75:M354-9. doi: 10.1111/j.1750-3841.2010.01671.x

79. Gerez CL, Torres MJ, Font de Valdez G, Rollán G. Control of spoilage fungi by lactic acid bacteria. Biol Control 2013;64:231-7. doi: 10.1016/j.biocontrol.2012.10.009

80. Oranusi S, Braide W, Oguoma OI. Antifungal properties of lactic acid bacteria (LAB) isolated from Ricinus communis, Pentaclethra macrophylla and yoghurts. Glo Adv Res J Food Sci Technol 2013;2:1-6.

81. Schillinger U, Villarreal JV. Inhibition of Penicillium nordicum in MRS medium by lactic acid bacteria isolated from foods. Food Control 2010;21:107-11. doi: 10.1016/j. foodcont.2008.11.010

82. Schaefer L, Auchtung TA, Hermans KE, Whitehead D, Borhan B, Britton RA. The antimicrobial compound reuterin (3-hydroxypropionaldehyde) induces oxidative stress via interaction with thiol groups. Microbiology 2010;156:158999. doi: 10.1099/mic.0.035642-0

83. Dalbello F, Clarke C, Ryan L, Ulmer H, Schober T, Ström K, Sjögren J, Vansinderen D, Schnurer J, Arendt E. Improvement of the quality and shelf life of wheat bread by fermentation with the antifungal strain Lactobacillus plantarum FST 1.7. J Cereal Sci 2007;45:309-18. doi: 10.1016/j.jcs.2006.09.004

84. Mandal V, Sen SK, Mandal NC. Detection, isolation and partial characterization of antifungal compound(s) produced by Pediococcus acidilactici LAB 5. Nat Prod Commun 2007;2:671-4.

85. Gerez LC, Torino IM, Rollan G, de Valdez FG. Prevention of bread mould spoilage by using lactic acid bacteria with antifungal properties. Food Control 2009;20:144-8. doi: 10.1016/j.foodcont.2008.03.005

86. Prema P, Smila D, Palavesam A, Immanuel G. Production and characterization of an antifungal compound (3-phenyllactic acid) produced by Lactobacillus plantarum strain. Food Bioprocess Tech 2010;3:379-86.

87. Schwenninger S, Lacroix C, Truttmann S, Jans C, Spörndli C, Bigler L. Characterization of low-molecular-weight antiyeast metabolites produced by a food-protective Lactobacillus-Propionibacterium coculture. J Food Prot 2008;71, 2481-7. PMID: 19244902 
88. Yang EJ, Chang HC. Purification of a new antifungal compound produced by Lactobacillus plantarum $\mathrm{AF}_{1}$ isolated from kimchi. Int J Food Microbiol 2010;139:56-63. doi: 10.1016/j.ijfoodmicro.2010.02.012

89. Eklund T. Organic acids and esters. In: Gould GW, editor Mechanisms of Action of Food Preservation Procedures. London: Elsevier Applied Science; 1989. p. 161-200.

90. Woolford MK. The antimicrobial spectra of some salts of organic acids and glutaraldehyde in respect to their potential as silage additives. Grass Forage Sci 1984;39:53-7. doi: 10.1111/j.1365-2494.1984.tb01664.x

91. Langa S, Martín-Cabrejas I, Montiel R, Landete JM, Medina $\mathrm{M}$, Arqués JL. Combined antimicrobial activity of reuterin and diacetyl against foodborne pathogens. J Dairy Sci 2014;97:6116-21. doi: 10.3168/jds.2014-8306

92. Corsetti A, Gobetti M, Rossi J, Damiani P. Antimould activity of sourdough lactic acid bacteria: identification of a mixture of organic acids produced by Lactobacillus sanfrancisco CB1. Appl Microbiol Biotechnol 1989;50:253-6. doi: 10.1007/s002530051285

93. Dalié DKD, Deschamps AM, Richard-Forget F. Lactic acid bacteria - Potential for control of mould growth and mycotoxins: A review. Food Control 2010;21:370-80. doi: 10.1016/j.foodcont.2009.07.011

94. Bovo F, Corassin CH, Rosim RE, de Oliveira CAF. Efficiency of lactic acid bacteria strains for decontamination of aflatoxin $\mathrm{M}_{1}$ in phosphate buffer saline solution and in skimmed milk. Food Bioprocess Technol 2013;6:2230-4. doi: 10.1007/ s11947-011-0770-9

95. Suarez-Quiroz ML, Gonzalez-Rios O, Champion-Martinez EI, Angulo O. Effects of lactic acid bacteria isolated from fermented coffee (Coffea arabica) on growth of Aspergillus ochraceus and ochratoxin A production. In: Proceedings of $22^{\text {nd }}$ International Conference on Coffee Science, ASIC 2008; 14-19 September 2008; Campinas, SP Brazil. Paris: Association Scientifique Internationale du Café (ASIC); 2008. p. 542-6.

96. Niderkorn V, Boudra H, Morgavi DP. Binding of Fusarium mycotoxins by fermentative bacteria in vitro. J Appl Microbiol 2006;101:849-56. doi: 10.1111/j.1365-2672. 2006.02958.x

97. Abbès S, Salah-Abbès JB, Sharafi H, Oueslati R, Noghabi KA. Lactobacillus paracasei BEJ01 prevents immunotoxic effects during chronic zearalenone exposure in Balb/c mice. Immunopharmacol Immunotoxicol 2013;35:341-8. doi: 10.3109/08923973.2013.772194

98. Zou ZY, He ZF, Li HJ, Han PF, Meng X, Zhang Y, Zhou F, Ouyang KP, Chen XY, Tang J. In vitro removal of deoxynivalenol and T-2 toxin by lactic acid bacteria. Food Sci Biotechnol 2012;21:1677-83. doi: 10.1007/s10068-0120223-x

99. Hawar S, Vevers W, Karieb S, Ali BK, Billington R, Beal J. Biotransformation of patulin to hydroascladiol by Lactobacillus plantarum. Food Control 2013;34:502-8. doi: 10.1016/j.foodcont.2013.05.023

100. Zinedine A, Faid M, Benlemlih M. In vitro reduction of aflatoxin $\mathrm{B}_{1}$ by strains of lactic acid bacteria isolated from Moroccan sourdough bread. Int J Agric Biol 2005;7:67-70.

101. Piotrowska M, Zakowska Z. The elimination of ochratoxin A by lactic acid bacteria strains. Pol J Microbiol 2005;54:27986. PMID: 16599298
102. El-Nezami H, Polychronaki N, Lee YK, Haskard C, Juvonen R, Salminen S, Mykkänen H. Chemical moieties and interactions involved in the binding of zearalenone to the surface of Lactobacillus rhamnosus strains GG. JAgric Food Chem 2004;52:4577-81. doi: 10.1021/jf049924m

103. Hatab S, Yue T, Mohamad O. Removal of patulin from apple juice using inactivated lactic acid bacteria. J Appl Microbiol 2012;112:892-9. doi: 10.1111/j.1365-2672.2012.05279.x

104. Franco TS, Garcia S, Hirooka EY, Ono YS, dos Santos JS. Lactic acid bacteria in the inhibition of Fusarium graminearum and deoxynivalenol detoxification. J Appl Microbiol 2011;111:739-48. doi: 10.1111/j.1365-2672.2011.05074.x

105. Niderkorn V, Morgavi DP, Pujos E, Tissandier A, Boudra H. Screening of fermentative bacteria for their ability to bind and biotransform deoxynivalenol, zearalenone and fumonisins in an in vitro simulated corn silage model. Food Addit Contam 2007;24:406-15. doi: $10.1080 / 02652030601101110$

106. Bolognani F, Rumney CJ, Rowland IR. Influence of carcinogen binding by lactic acid-producing bacteria on tissue distribution and in vitro mutagenecity of dietary carcinogens. Food Chem Toxicol 1997;35:535-45. PMID: 9225011

107. Orrihage KE, Sillerström E, Gustafsson JA, Nord CE, Rafter $\mathrm{J}$. Binding of mutagenic heterocyclic amines by intestinal lactic acid bacteria. Mutat Res 1994;311:239-48. doi: 10.1016/0027-5107(94)90182-1

108. Zhang XB, Ohta Y. Binding of mutagens by fractions of the cell wall skeleton of lactic acid bacteria on mutagens. J Dairy Sci 1991;74:1477-81. doi: 10.3168/jds.S00220302(91)78306-9

109. Haskard CA, El-Nezami H, Kankaanpaa PE, Salminen S, Ahokas JT. Surface binding of aflatoxin $\mathrm{B}_{1}$ by lactic acid bacteria. Appl Environ Microbiol 2001;67:3086-91. doi: 10.1128/AEM.67.7.3086-3091.2001

110. Bueno DJ, Casale CH, Pizzolitto RP, Salano MA, Olivier G. Physical adsorption of aflatoxin $\mathrm{B}_{1}$ by lactic acid bacteria and Saccharomyces cerevisiae: A theoretical model. J Food Protect 2006;70:2148-54. doi: 10.4315/0362-028X70.9.2148

111. Čvek D, Markov K, Frece J, Friganović M, Duraković L, Delaš F. Adhesion of zearalenone to the surface of lactic acid bacteria cells. Croat J Food Technol Biotechnol Nutr 2012;7(Special Issue):49-52.

112. Corassin CH, Bovo F, Rosim RE, Oliveira CAF. Efficiency of Saccharomyces cerevisiae and lactic acid bacteria strains to bind aflatoxin $M_{1}$ in UHT skim milk. Food Control 2013;31:80-3. doi: 10.1016/j.foodcont.2012.09.033

113. Khoury AE, Atoui A, Yaghi J. Analysis of aflatoxin $M_{1}$ in milk and yogurt and AFM1 reduction by lactic acid bacteria used in Lebanese industry. Food Control 2011;22:1695-9. doi: 10.1016/j.foodcont.2011.04.001

114. Dogi CA, Fochesato A, Armando R, Pribull B, de Souza MMS, da Silva Coelho I, Araújo de Melo D, Dalcero A, Cavaglieri L. Selection of lactic acid bacteria to promote an efficient silage fermentation capable of inhibiting the activity of Aspergillus parasiticus and Fusarium gramineraum and mycotoxin production. J Appl Microbiol 2013;114:1650-60. doi: $10.1111 /$ jam. 1217

115. Fazeli MR, Hajimohammadali M, Moshkani A, Samadi N, Jamalifar H, Khoshayand MR, Vaghari E, Pouragahi S. Aflatoxin $\mathrm{B}_{1}$ binding capacity of autochthonous strains of 
lactic acid bacteria. J Food Protect 2009;72:189-92. doi: 10.4315/0362-028X-72.1.189

116. Sezer C, Güven A, Bilge Oral N, Vatansever L. Detoxification of aflatoxin $\mathrm{B}_{1}$ by bacteriocins and bacteriocinogenic lactic acid bacteria. Turk J Vet Anim Sci 2013;37:594-601. doi:10.3906/vet-1301-31

117. Motameny R, Sadeghi AA, Dehghan-Banadaky M, Chamani $\mathrm{M}$, Abolhassani M. Effect of some acid treated bacteria on reduction of impure aflatoxin $B_{1}$ in ruminant gastrointestinal model. J Am Sci 2012;7:213-7.

118. Oluwafemi F, Kumar M, Bandyopadhyay R, Ogunbanwo T, Ayanwande KB. Bio-detoxification of aflatoxin $\mathrm{B}_{1}$ in artificially contaminated maize grains using lactic acid bacteria. Toxins Rev 2010;29:115-22. $10.3109 / 15569543.2010 .512556$

119. Serrano-Niño JC, Cavazos-Garduño A, Hernandez-Mendoza A, Applegate B, Ferruzzi MG, San Martin-González MF, García HS. Assessment of probiotic strains ability to reduce the bioaccessibility of aflatoxin $\mathrm{M}_{1}$ in artificially contaminated milk using an in vitro digestive model. Food Control 2013;31:202-7. doi: 10.1016/j.foodcont.2012.09.023

120. Elsanhoty RM, Ramadan MF, El-Gohery SS, Abol-Ela MF, Azeke MA. Ability of selected microorganisms for removing aflatoxins in vitro and fate of aflatoxins in contaminated wheat during baladi bread baking. Food Control 2013;33:287-92 doi: 10.1016/j.foodcont.2013.03.002

121. Kabak B, Ozbey F. Assessment of the bioaccessibility of aflatoxins from various food matrices using an in vitro digestion model, and the efficacy of probiotic bacteria in reducing bioaccessibility. J Food Composit Anal 2012;27:2131. doi: 10.1016/j.jfca.2012.04.006

122. Kasmani FB, Torshizi MAK, Allameh AA, Shariatmadari F. Aflatoxin detoxification potential of lactic acid bacteria isolated from Iranian poultry. Iran J Vet Res 2012;13:152-5. doi: 10.22099/IJVR.2012.117

123. Hernandez-Mendoza A, Garcia HS, Steele JL. Screening of Lactobacillus casei strains for their ability to bind aflatoxin $B_{1}$. Food Chem Toxicol 2009;47:1064-8. doi: 10.1016/j. fct.2009.01.042

124. Hernandez-Mendoza A, Guzman-de-Peña D, Garcia HS. Key role of teichoic acids on aflatoxin $\mathrm{B}_{1}$ binding by probiotic bacteria. J Appl Microbiol 2009;107:395-403. doi: 10.1111/j.1365-2672.2009.04217.x

125. Hathout AS, Mohamed SR, El-Nekeety AA, Hassan NS, Aly SE, Abdel-Wahha MA. Ability of Lactobacillus casei and Lactobacillus reuteri to protect against oxidative stress in rats fed aflatoxins-contaminated diet. Toxicon 2011;58:17986. doi: 10.1016/j.toxicon.2011.05.015

126. Fernández-Jur, MG, Muzzolón JA, Dalcero AM, Magnoli CE. Effect of acid lactic bacteria isolated from faeces of healthy dogs on growth parameters and aflatoxin $\mathrm{B}_{1}$ production by Aspergillus species in vitro. Mycotoxin Res 2011;27:273-80. doi: 10.1007/s12550-011-0104-9

127. Topcu A, Bulat T, Wishah R, Boyac1 IH. Detoxification of aflatoxin $\mathrm{B}_{1}$ and patulin by Enterococcus faecium strains. Int J Food Microbiol 2010;139:202-5. doi: 10.1016/j. ijfoodmicro.2010.03.00

128. Fuchs S, Sontag G, Stidl R, Ehrlich V, Kundi M, Knasmuller S. Detoxification of patulin and ochratoxin A, two abundant mycotoxins, by lactic acid bacteria. Food Chem Toxicol 2008;46:1398-407. doi: 10.1016/j.fct.2007.10.008
129. Skrinjar M, Rasic JL, Stojicic V. Lowering of ochratoxin A level in milk by yoghurt bacteria and bifidobacteria. Folia Microbiol (Praha) 1996;41:26-8. Lowering of ochratoxin A level in milk by yoghurt bacteria and bifidobacteria

130. Kapetanakou AE, Kollias JN, Drosinos EH, Skandamis PN. Inhibition of $A$. carbonarius growth and reduction of ochratoxin A by bacteria and yeast composites of technological importance in culture media and beverages. Int J Food Microbiol 2012;152:91-9. doi: 10.1016/j. ijfoodmicro.2011.09.010

131. Piotrowska M, Zakowska Z. The biodegradation of ochratoxin A in food products by lactic acid bacteria and baker's yeast. Progress Biotechnol 2000;17:307-10. doi: 10.1016/S0921-0423(00)80085-4

132. Mateo EM, Medina A, Mateo F, Valle-Algarra FM, Pardo I, Jiménez M. Ochratoxin A removal in synthetic media by living and heat-inactivated cells of Oenococcus oeni isolated from wines. Food Control 2010;21:23-8. doi: 10.1016/j. foodcont.2009.03.012

133. Niderkorn V, Morgavi DP, Aboab B, Lemaire M, Boudra H. Cell wall component and mycotoxin moieties involved in the binding of fumonisin $\mathrm{B}_{1}$ and $\mathrm{B}_{2}$ by lactic acid bacteria. J Appl Microbiol 2009;106:977-85. doi: 10.1111/j.1365-2672. 2008.04065.x

134. El-Nezami H, Polychronaki N, Salminen S, Mykkänen H. Binding rather than metabolism may explain the interaction of two food-grade Lactobacillus strains with zearalenone and its derivative $\alpha$-zearalenol. Appl Environ Microbiol 2002;68:3545-9. doi: 10.1128/AEM.68.7.3545-3549.2002

135. Niderkorn V, Boudra H, Morgavi DP. Stability of the bacteriabound zearalenone complex in ruminal fluid and in simulated gastrointestinal environment in vitro. World Mycotoxin Journal 2008;1:463-7. doi: 10.3920/WMJ2007.1010

136. Hatab S, Yue T, Mohamad O. Reduction of patulin in aqueous solution by lactic acid bacteria. J Food Sci 2012;77:M238-41. doi: 10.1111/j.1750-3841.2011.02615.x

137. Reddy KRN, Saritha P, Reddy CS, Muralidharan K. Aflatoxin $\mathrm{B}_{1}$ producing potential of Aspergillus flavus strains isolated from stored rice grains. Afr J Biotechnol 2009;8:3303-8.

138. Yu J, Cleveland TE, Nierman WC, Bennett JW. Aspergillus flavus genomics: gateway to human and animal health, food safety, and crop resistance to diseases. Rev Iberoam Micol 2005;22:194-202. doi: 10.1016/S1130-1406(05)70043-7

139. Zrari TJO. Detection of aflatoxin from some Aspergillus sp. isolated from wheat seeds. J Life Sci 2013;7:1041-7.

140. Frisvad JC, Skouboe P, Samson RA. Taxonomic comparison of three different groups of aflatoxin producers and a new efficient producer of aflatoxin $\mathrm{B}_{1}$, sterigmatocystin and 3-O-methylsterigmatocystin, Aspergillus rambellii sp. nov. Syst Appl Microbiol 2005;28:442-53. doi: 10.1016/j. syapm.2005.02.012

141. Ostry V, Ruprich J, Skarkova J, Prochazkova I, Kubatova A. Occurrence of the toxigenic fungi (producers of aflatoxins and ochratoxin A) in foodstuffs in the Czech Republic 19992000. Mycotoxin Res 2001;17(Suppl 2):188-92. doi: 10.1007/BF03036433

142. Jakić-Dimić D, Nešić K, Petrović M. Contamination of cereals with aflatoxins, metabolites of fungi Aspergillus flavus. Biotechnol Anim Husbandry 2009;25:1203-8.

143. Aydin A, Gunsen U, Demirel S. Total aflatoxin, aflatoxin B and ochratoxin A levels in Turkish wheat flour. J Food Drug Anal 2018;16:48-53. 
144. Giray B, Girgin G, Engin AB, Aydin S, Sahin G. Aflatoxin levels in wheat samples consumed in some regions of Turkey. Food Control 2007;18:23-9. doi: 10.1016/j. foodcont.2005.08.002

145. Toteja GS, Mukherjee A, Diwakar S, Singh P, Saxena BN, Sinha KK, Sinh AK, Kumar N, Nagaraja KV, Bai G, Prasad CA, Vanchinathan S, Roy R, Parkar S. Aflatoxin B contamination in wheat grain samples collected from different geographical regions of India: A multicenter study. J Food Protect 2006;69:1463-7. doi: 10.4315/0362-028X69.6.1463

146. Battilani P, Toscano P, Van der Fels-Klerx HJ, Moretti A, Camardo Leggieri M, Brera C, Rortais A, Goumperis T, Robinson T. Aflatoxin $\mathrm{B}_{1}$ contamination in maize in Europe increases due to climate change. Sci Rep 2016;6:24328. doi: 10.1038/srep24328

147. Saini SS, Kaur A. Aflatoxin $B_{1}$ : Toxicity, characteristics and analysis: Mini review. Global Adv Res J Chem Mater Sci 2012;1:63-70.

148. Abbas HK, Cartwrihgt RD, Wie W, Shier WT. Aflatoxin and fumonisin contamination of corn (maize, Zea mays) hybrids in Arkansas. Crop Protection 2006;251-259. doi: 10.1016/j. cropro.2005.02.009

149. Jakšić SM, Abramović BF, Prunić BZ, Mihaljev ZA, Baloš MMZ, Jajić IM, Despotović VN, Bjelica LJ. Incidence of aflatoxins and fumonisins in cereal food from Serbian market. J Agroalim Proc Technol 2011;17:108-12.

150. Sassahara M, Pontes Netto M, Yanaka EK. Aflatoxin occurrence in foodstuff sopplied to dairy cattle and aflatoxin $\mathrm{M}_{1}$ in raw milk in the North of Parana state. Food Chem Toxicol 2005;43:981-4. doi: 10.1016/j.fct.2005.02.003

151. Shar ZH, Sumbal GA, Sherazi STH, Bhangar MI, Nizamani SM. Natural co-occurence of aflatoxins and deoxynivalenol in poultry feed in Pakistan. Food Addit Contamin Part B Surveill 2014;7:162-7. doi: 10.1080/19393210.2013.867904

152. Zinedine A, Juan C, Soriano JM, Idrissi L, Manes J. Limited survey for the occurrence of aflatoxins in cereals and poultry feeds from Rabat, Morocco. Int J Food Microbiol 2007;115:124-7. doi: 10.1016/j.ijfoodmicro.2006.10.013

153. Elmholt S, Rasmussen PH. Penicillium verrucosum occurrence and ochratoxin A contents in organically cultivated grain with special reference to ancient wheat types and drying practice. Mycopathologia 2005;159:421-32.DOI: 10.1007/s11046-005-1152-5

154. Ostry V, Malir F, Ruprich J. Producers and important dietary sources of ochratoxin A and citrinin. Toxins (Basel) 2013;5:1574-86. doi: 10.3390/toxins5091574

155. Reddy L, Bhoola K. Ochratoxins-food contaminants: impact on human health. Toxins (Basel) 2010;2:771-9. doi: 10.3390/ toxins 2040771

156. Noonim P, Mahakarnchanakul W, Nielsen KF, Frisvad JC, Samson RA. Isolation, identification and toxigenic potential of ochratoxin A-producing Aspergillus species from coffee beans grown in two regions of Thailand. Int J Food Microbiol 2008;128:197-202. doi: 10.1016/j.ijfoodmicro.2008.08.00

157. Böhm J, Grajewski J, Asperger H, Cecon B, Rabus B, Razzazi E. Study on biodegradation of some A- and B-trichothecenes and ochratoxin A by use of probiotic microorganisms. Mycotoxin Res 2000;16(Suppl 1):70-4. doi: 10.1007/ BF02942985
158. Gelderblom T, Jaskiewicz WCA, Marasas WFO, Thiel PG, Horak MJ, Vleggaar R, Kriek NPJ. Fumonisins-novel mycotoxins with cancer promotion activity produced by Fusarium moniliforme. Appl Environ Microbiol 1988;54:1806-11. PMCID: PMC202749

159. Stępień $€$, Koczyk G, Waśkiewicz A. FUM cluster divergence in fumonisins-producing Fusarium species. Fungal Biol 2011;115:112-23. doi: 10.1016/j.funbio.2010.10.011

160. Stępień $Ł$, Koczyk G, Waśkiewicz A. Genetic and phenotypic variation of Fusarium proliferatum isolates from different host species. J Appl Genet 2011;52:487-96. doi: 10.1007/ s13353-011-0059-8

161. Frisvad JC, Larsen TO, Thrane U, Meijer M, Varga J, Samson RA, Nielsen KF. Fumonisin and ochratoxin production in ndustrial Aspergillus niger strains. PLoS One 2011;6(8):e23496. doi: 10.1371/journal.pone.0023496

162. Waśkiewicz A, Beszterda M, Goliński P. Occurrence of fumonisins in food - an interdisciplinary approach to the problem. Food Control 2012;26:491-9. doi: 10.1016/j. foodcont.2012.02.007

163. Waśkiewicz A, Irzykowska L, Bocianowski J, Karolewski Z, Weber Z, Goliński P. Fusariotoxins in asparagus - their biosynthesis and migration. Food Addit Contam Part A Chem Anal Control Expo Risk Assess 2013;30:1332-8. doi: 10.1080/19440049.2013.796095

164. Danicke S, Swiech E, Buraczewska L, Ueberschär K-H. Kinetics and metabolism of zearalenone in young female pigs. J Anim Physiol Anim Nutr 2005;89:268-76. doi: 10.1111/j.1439-0396.2005.00516.x

165. Ezekiel CN, Odebode AC, Fapohunda SO. Zearalenone production by naturally occurring Fusarium species on maize, wheat and soybeans from Nigeria. J Biodiver Environ Sci 2008;2:77-82.

166. Ferreira Geraldo MR, Tessmann DJ, Kemmelmeier C. Production of mycotoxins by Fusarium graminearum isolated from small cereals (wheat, triticale and barley) affected with scab disease in Southern Brazil. Braz J Microbiol 2006;37:58-63. doi: 10.1590/S151783822006000100011

167. Zwierzchowski W, Przybyłowicz M, Obremski K, Zielonka Ł, Skorska-Wyszyńska E, Gajęcka M, Polak M, Jakimiuk E, Jana B, Rybarczyk L, Gajęcki M. Level of zearalenone in blood serum and lesions in ovarian follicles of sexually immature gilts in the course of zearalenone mycotoxicosis. Pol J Vet Sci 2005;8:209-18. PMID: 16180582

168. Abbès S, Salah-Abbès JB, Sharafi H, Noghabi KA, Oueslati R. Interaction of Lactobacillus plantarum MON03 with Tunisian Montmorillonite clay and ability of the composite to immobilize zearalenone in vitro and counteract immunotoxicity in vivo. Immunopharmacol Immunotoxicol 2012;34:944-50. doi: 10.3109/08923973.2012.674139

169. Foroud NA, Eudes F. Trichothecenes in cereal grains. Int J Mol Sci 2009;10:147-73. PMCID: PMC2662451

170. Kushiro M. Effects of milling and cooking processes on the deoxynivalenol content in wheat. Int J Mol Sci 2008;9:212745. doi: 10.3390/ijms9112127

171. Welugo SN. Factors influencing deoxynivalenol accumulation in small grain cereals. Toxins (Basel) 2012;4:1157-80. doi: $10.3390 /$ toxins 4111157 


\section{Djelotvornost mliječnokiselinskih bakterija protiv patogenih plijesni i mikotoksina}

Mikotoksini su sekundarni proizvodi pojedinih vrsta plijesni rodova Aspergillus, Penicillium i Fusarium koji često zagađuju raznovrsne prehrambene proizvode. Stoga se u suzbijanju tih plijesni i zagađenja mikotoksinima primjenjuju mnoge strategije kroz cijeli prehrambeni lanac. U ovome se prikazu raspravlja o primjeni mliječnokiselinskih bakterija, kojima se već stoljećima sprječava razvoj i rast plijesni, a koje sudjeluju i u razgradnji mikotoksina i/ili u njihovu uklanjanju iz zagađene hrane. Budući da su korisne za ljudsko i životinjsko zdravlje, mliječnokiselinske bakterije izvrsno su rješenje problema sa zagađenjem mikotoksinima, ali je njihova primjena još pred izazovima, koje će riješiti buduća istraživanja.

KLJUČNE RIJEČI: Aspergillus; biološke metode; Fusarium; inhibicija; LAB; Penicillium 